\title{
BMJ Global Health Managing an epidemic in imperfect times: encampment and immunity passes in 19th century Gibraltar
}

\author{
Lawrence Alexander Sawchuk, ${ }^{1}$ Lianne Tripp ${ }^{2}$
}

To cite: Sawchuk LA, Tripp L. Managing an epidemic in imperfect times: encampment and immunity passes in 19th century Gibraltar. BMJ Global Health 2021;6:006713. doi:10.1136/ bmjgh-2021-006713

Handling editor Seye Abimbola

- Additional material is published online only. To view, please visit the journal online (http://dx.doi.org/10.1136/ bmjgh-2021-006713).

Received 24 June 2021 Accepted 14 July 2021
A Check for updates

(C) Author(s) (or their employer(s)) 2021. Re-use permitted under CC BY-NC. No commercial re-use. See rights and permissions. Published by BMJ.

${ }^{1}$ Anthropology, University of Toronto Scarborough, Toronto, Ontario, Canada

${ }^{2}$ Anthropology, University of Northern British Columbia, Prince George, British Columbia, Canada

\section{Correspondence to} Dr Lawrence Alexander Sawchuk;

lawrence.sawchuk@utoronto.ca

\section{INTRODUCTION}

As the COVID-19 pandemic surpasses a year for many populations around the world, there has been renewed interest in what the future holds for new and innovative non-pharmaceutical interventions as well as an interest in measures of the past and how they have evolved over time. While considerable attention has been placed on contrasts and parallels with the 1918/1919 influenza pandemic, one may ask are there any valuable lessons that we can learn about managing an epidemic when knowledge of the aetiology of diseases was imperfect? One such example of forward-thinking, centralised and proactive mitigation strategies dates back to the nineteenth century yellow fever epidemics in Gibraltar.

\section{A COMPLIANT POPULATION IN A UNIQUE SETTING}

As a peninsula with a limited territory of only $6.7 \mathrm{~km}^{2}$, bounded by three sides of sea and Spain to the north, Gibraltar was a British colony and garrison town under strict military governance and police surveillance. Gibraltar was uniquely positioned to enforce pre-emptive and restrictive measures; residents in a walled fortress, civilians had neither voice nor autonomy as absolute power was vested in a military governor. ${ }^{1}$ Movement in and out of the gated city was controlled through an elaborate permit system, by which sunrise and sunset marked times of permissible civilian movement (see online supplemental figure 1).

\section{DEATH IN UNPRECEDENTED NUMBERS: THE 1804 EPIDEMIC}

In September 1804, Gibraltar was struck by a deadly "pestilential fever'" and within the space of four short months, it was reported that 'upwards of 2200' had perished.. ${ }^{3}$ Although the local newspaper reported 4864 deaths of inhabitants, ${ }^{5}$ this was most likely an inflated number to secure much needed

\section{Summary box}

Yellow fever pandemics of the 1800s were feared because of the lethal toll it placed on population, yet the epidemics have been overlooked in the pandemics literature.

- In Gibraltar, the use of the Neutral Ground as place for quarantine and a marketplace (the Pallenque) at the cordon line with Spain, began during the 1810 yellow fever epidemic

- In 1828, meticulous house-to-house surveys were used to distinguish those who had passed through an epidemic from the non-immune individuals (approximately 4000 ), who had to be sequestered and monitored at the Neutral Ground encampment for 4 months.

- By 1828, fever passes were issued to those who were known to have passed through the fever, which gave the pass holder the liberty to move in and out of the fortress.

- Parallels to the nineteenth century fever passes and quarantine of the thousands of people at the Neutral Ground can be made to the current global COVID-19 pandemic.

financial support for rebuilding the fortress and its infrastructure. Yellow fever ravaged Gibraltar and Spain in greater numbers than all the countries in Europe combined. ${ }^{6}$ The yellow fever death rate was 128.83 per 1000 in the lower Iberian Peninsula, in other words by the end of the epidemic in December 1804 , about one-eighth of the population had died of the virus. ${ }^{7}$

In January of 1805, a Board of Public Health was established, but there was not a resolution to the mode of transmission because there was considerable debate revolving around miasmatic and contagionist perspectives. The predominant belief in the early nineteenth century was that of the neo-Hippocratic hypothesis, whereby a combination of environmental conditions (such as temperature, precipitation and soil) was thought to activate the 'contagion'. While there was little 
doubt that the appearance of the disease was seasonal, only some viewed it as a disease of importation. ${ }^{8}$ By 1814 , many in Gibraltar viewed yellow fever as an infectious disease that was spread from person to person ${ }^{910}$ (this was not a common view elsewhere ${ }^{11}$ ), and that once recovered from the fever, the individual was no longer liable to second attack. ${ }^{910}$

\section{THE EMERGENCE OF COUNTERMEASURES}

In the fall of 1810, when a few yellow fever cases appeared, there was considerable fear and anxiety that there would be a repeat of the 1804 crisis. Consequently, health authorities implemented a series of novel and transformative measures. The first was an introduction of a special marketplace, the Pallenque, ${ }^{12}$ in response to the imposition of a sanitary cordon by Spain. Under the watchful eyes of the police on either side of the border, specific regulations were put in place for the continued flow of food and other necessities. The second order of action was that the authorities swiftly and secretly established a place for isolation at the Neutral Ground. In the middle of the night, the sick in the town, were forcibly removed from their houses and sent to the encampment. ${ }^{3}{ }^{12}$ Placed under guard in a series of tents, the sick remained in isolation until 24th November. When yellow fever struck again in 1813/1814, the practice of the removal of the ill to the Neutral Ground had become an entrenched practice.

After the 1814 epidemic, the government took a bold step by enlisting the cooperation of civilian volunteers to monitor the health of the garrison town. ${ }^{12}$ In May 1815, the inspectors for each of the 34 administrative districts would provide regular reports to the authorities on matters of health such as overcrowding, cleanliness and sickness. Only those who had passed through an earlier epidemic were permitted to volunteer. Assisted by the police, the volunteers conducted daily house-to-house surveys to identify those who had gone through the epidemic and those who remained susceptible; they were also assigned to purify and fumigate the homes of the sick. ${ }^{12}$

\section{THE 'GRAND MEASURE' AND THE TRANSITION TO PROTECTIVE SEQUESTRATION}

In late August 1828, yellow fever returned to Gibraltar. Building on the earlier collective measures, two new important actions were introduced.

First, on 6th September, a day after the erection of the cordon by Spain, British authorities ordered individuals and households who had not passed the fever to immediately relocate to the Neutral Ground. All others could remain in the Garrison. The Principal Medical Officer of Health (PMOH), referred to this action as the 'Grand Measure', which also involved diminishing the size of the population through the removal of unnecessary foreign labourers. ${ }^{3}$ By the close of the 1828 epidemic, about 4000 civilians resided at the encampment for upwards of 4 months. The Neutral Ground encampment located at the northern border with Spain, which also held the

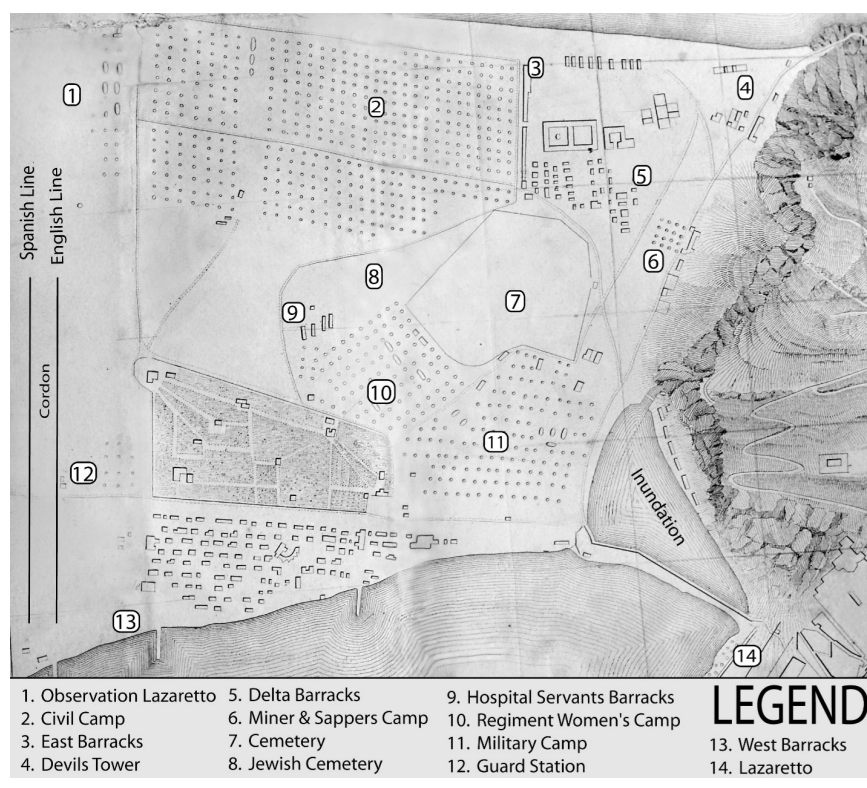

Figure 1 Map of yellow fever encampment at the Neutral Ground. ${ }^{14}$ Adapted by Ken Jones from Chervin, 1830.

military, was estimated to be half a mile long by onesixteenth of a mile in width and "consisting of about 100 wooden houses, laid about in parallel and cross streets.... ${ }^{13}$ Figure 1 shows the layout of the encampment. ${ }^{14}$ Three civilian medical practitioners monitored the health of those living in the encampment and the police patrolled the streets daily.

Second, the encampment served as a centre for aid relief. Food was provided by private charitable donations, and shelter was provided by the Colonial Government. Spain liberally provided food at the Pallenque. Furthermore, the Spanish King donated a substantial contribution of wheat and flour for feeding the poor. ${ }^{12}$

The encampment appeared to control the spread of the disease as the yellow fever death rate at the hospital in the encampment was 19.75 per 1000 , while yellow fever mortality was 103.90 per 1000 living in the town. ${ }^{15}$ The limited spread of the disease was largely attributed to the lack of the mosquito (Aedes aegypti), because there was not abundance of standing water at the Neutral Ground, which would have served as breeding sites for as well the fact that the winds would have hampered the flight of mosquitoes. Even though yellow fever is not a contagious disease, the act of segregation and sequestrating of the healthy subsection of the population required meticulous contact tracing, a scale of undertaking that was formidable, considering it predated knowledge of the bacterial revolution.

\section{IMMUNITY AND THE FEVER PASS}

By 1828 , with the knowledge that a person who survived yellow fever conferred immunity, the health officials introduced the fever pass. Any individual who produced a certificate from a physician, stating that he or she had been infected with the disease in a previous epidemic, 


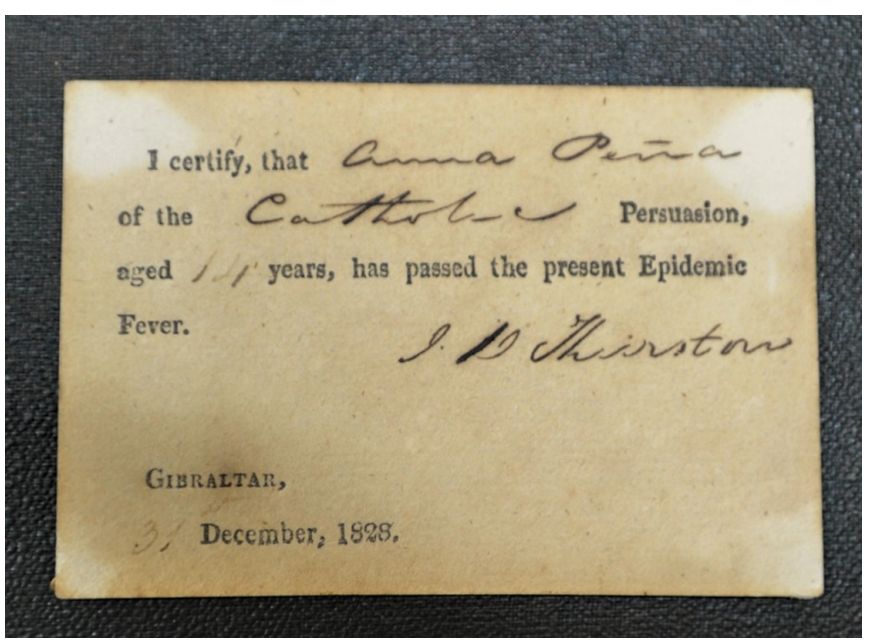

Figure 2 Immunity pass from 1828 yellow fever epidemic (photographed by LA Sawchuk with permission from the Gibraltar Museum).

was allowed to continue to reside in the town and travel in and out of the town. ${ }^{12}$ For those residing in the camp and holding a pass, they could go to work daily in the town or enter the town to retrieve personal belongings. Those who had not passed through the fever had to reside and remain in the encampment.

The Gibraltar immunity pass, shown in figure 2, was also used in Spain. Gibraltar's printed immunity passes may perhaps be the earliest surviving example because there is not any documentation of similar passports in the literature (see online supplemental figure 2) In urban late nineteenth century New Orleans, where yellow fever was rampant, immunity to yellow fever was not officially certified by a doctor but was based on an honour system whereby individuals claimed to have survived or 'acclimated' to the disease, especially among those who had immigrated to the state from a non-endemic yellow fever country. ${ }^{16}$ Unlike the health passports that originated out of the fifteenth century plague epidemics, which certified an individual could travel freely because they came from a city free of the disease, ${ }^{17}$ the Gibraltar passes signified that the holder was no longer susceptible to yellow fever.

\section{CONCLUSION}

Parallels in the management of modern-day yellow fever vaccination and travel by the International Health Regulations are made to that of emerging COVID-19 vaccination passport programmes. ${ }^{18}$ The nineteenth century yellow fever countermeasures in Gibraltar are equally comparable. Gibraltar, now a British Overseas Territory, was one of the first nations in the world to complete the COVID-19 vaccination of their adult population, those who have been vaccinated were issued cards. As of March 2021, Gibraltar was preparing a COVID-19 passport valid for the EU and UK. In January 2020, in outskirts of Shijiazhuang in China, there was a rush to build an encampment to quarantine 4000 people, who may have come in contact with a person infected with COVID-19.
Gibraltar's nineteenth century yellow fever encampment at the Neutral Ground was an early example of the modern-day large-scale and complex quarantine strategy.

Acknowledgements We would like to thank Dr. Clive Finlayson, Director of the Gibraltar Museum, for granting access to photograph the permits.

Contributors Both authors have contributed equally to the development of this manuscript.

Funding The authors have not declared a specific grant for this research from any funding agency in the public, commercial or not-for-profit sectors.

Map disclaimer The inclusion of any map (including the depiction of any boundaries therein), or of any geographic or locational reference, does not imply the expression of any opinion whatsoever on the part of BMJ concerning the legal status of any country, territory, jurisdiction or area or of its authorities. Any such expression remains solely that of the relevant source and is not endorsed by BMJ. Maps are provided without any warranty of any kind, either express or implied.

\section{Competing interests None declared.}

Patient consent for publication Not required.

Provenance and peer review Not commissioned; externally peer reviewed.

Data availability statement Data are available upon request.

Open access This is an open access article distributed in accordance with the Creative Commons Attribution Non Commercial (CC BY-NC 4.0) license, which permits others to distribute, remix, adapt, build upon this work non-commercially, and license their derivative works on different terms, provided the original work is properly cited, appropriate credit is given, any changes made indicated, and the use is non-commercial. See: http://creativecommons.org/licenses/by-nc/4.0/.

\section{REFERENCES}

1 Finlayson TJ. The fortress came first. Grendon, Northants: Gibraltar Books Ltd, 1991.

2 Sawchuk LA, Burke SD. Gibraltar's 1804 yellow fever scourge: the search for scapegoats. J Hist Med Allied Sci 1998;53:3-42.

3 Benady SG. Civil hospital and epidemics in Gibraltar. Grendon, Northants: Gibraltar Books Ltd, 1994.

4 Trigge ST. Letter from the Lieutenant-Governor to the Gibraltar chronicle, 1805.

5 Gillbard GJ. The Gibraltar directory: a guide book to the principal objects of interest in Gibraltar and the neighbourhood, with a condensed history of the famous rock., 1887. Garrison library printing establishment

6 Augustin G. History of yellow fever. Searcy \& Pfaff, 1909: 1-484.

7 Sawchuk L, Burke S. Through the looking glass. An anthropological reflection on the roots of the Gibraltarian people. Gibraltar: Memoirs GibCEMED, Gibraltar Museum, 1997: 1. 5-32.

8 S. Rodrigo F. The influence of meteorological conditions on the yellow fever epidemic in Cádiz (southern Spain) in 1800: a historical scientific controversy. Atmosphere 2020;11:405.

9 Rudge $\mathrm{H}$. To the editor of the Lancet: yellow fever at Gibraltar. The Lancet 1829;286:656.

10 Gill J. Of the yellow fever at Gibraltar: letter from Mr Gill to Mr. Blanshard. . Methodist Magazine, 1814: 37. 385-90.

11 Staples JE, Monath TP. Yellow fever: 100 years of discovery. JAMA 2008;300:960-2.

12 Sawchuk LA, Benady SG, Burke SDA. Passing through the fever: anatomy of an epidemic. Toronto: Diva Medi, 2005.

13 Hennen J. Sketches of the Mediterranean comprising an account of Gibraltar, the Ionian Islands, and Malta; to which is prefixed, a sketch of a plain for memoirs on medical topography. 100. London, England: Thomas and George Underwood, 1830.

14 Chervin MM. Louis et Trousseau, membres de al comminssion francaise enyoee a Gibraltar pour observer l'epidemie de 1828. Documens recuellis par...er par M. le Dr. Barry, medecin des armees anglaises. 2. Imprimerie royale, 1830.

15 Gibraltar chronicle (NO. 2242-2335), Sept 18-Dec 31., 1828

16 Olivarius K. Immunity, capital, and power in Antebellum new Orleans. Am Hist Rev 2019;124:425-55.

17 Bamji A. Health passes, print and public health in early modern Europe. Soc Hist Med 2019;32:441-64.

18 Vanderslott S, Marks T. Health diplomacy across borders: the case of yellow fever and COVID-19. J Travel Med 2020;27:taaa112. 